\title{
Manager Characteristics and the Choice of Firm "Low Leverage": Evidence from China
}

\author{
Yiping Chen, Xindong Zhang, Zhe Liu \\ School of Economic and Management, Shanxi University, Taiyuan, China \\ Email: chenyp710@sxu.edu.cn, zhangxd@sxu.edu.cn, dosiper@sina.com \\ Received 15 July 2014; revised 10 August 2014; accepted 6 September 2014 \\ Copyright $@ 2014$ by authors and Scientific Research Publishing Inc. \\ This work is licensed under the Creative Commons Attribution International License (CC BY). \\ http://creativecommons.org/licenses/by/4.0/

(c) (1) Open Access

\begin{abstract}
In this paper, we analyze the low-leverage phenomenon of firms and examine the question of why some firms have low leverage in China. We find Low-leverage firms are smaller, have higher profitability and hold more cash balances than control firms chosen by industry and size. Our evidence supports the hypothesis that these firms are operated by risk-aversion manager. Firms with older Chief Executive Officer (CEO) and higher first shareholder ownership are more likely to have low debt. Also, CEO gender is one of the determinants of low-leverage choice.
\end{abstract}

\section{Keywords}

Capital Structure, Low-Leverage Puzzle, Manager, Risk-Aversion, Gender

\section{Introduction}

In S\&P 500 index, there is a common phenomenon in some companies, such as Google, Apple, Texas Instruments, Bed Bath \& Beyond and Urban Outfitters: no debt. In 2001, there are 14\% US large-scale non-financial listed companies have neither current debt nor long-term debt. From 1962 to 2009, 10.2\% of the companies show no debt in their capital structure at average and 32\% of these firms have zero or negative net debt. That is, the cash of these firms is far more than their debt and there is a surplus even after pay back all the debt. Furthermore, it is not a temporary phenomenon, for $61 \%$ of the non-debt companies in any given year maintain the zero leverage in the next year. In the UK, from 1980 to 2007, 12.18\% of the companies follow zero leverage and $20.27 \%$ of the companies follow a considerable low leverage at the same time. It is also a continuously increasing trend that the proportion of zero leverage companies climbs from 3.41\% in 1983 to $24.35 \%$ in 2006.

In China, there exists the same phenomenon among the listed companies, such as Changcheng-Kaifa Technology, Shenzhen Huaqiang Industry, Foshan Electrical and Lighting, Kweichow Moutai, Shanghai Tongda Venture Capital, Sichuan Langsha Holding, etc., which do not use debt financing for years. There is neither cur- 
rent liability nor long-term liability in the capital structure of these companies and the companies stay debt-free. As a matter of fact, from the construction of China security market, as the amount of listed company increases, it appears an ascending tendency of the proportion of the debt-free companies. The proportion of zero leverage companies increased from only $1.5 \%$ in 1995 to $9.7 \%$ in 2011. In average, $6.4 \%$ of the companies had no debt between 1993 and 2011, 13.5\% of them take a leverage below 5\% and up to 58.5\% of them gives up the longterm debt ${ }^{1}$.

Why do so many companies deviate from the estimation of modern capital structure theory and follow a low leverage regardless the tax benefit? Are there any characteristics of the low leverage companies? How to explain this "low leverage puzzle" in the corporate financing which is not assorting with the modern capital structure theory?

\section{Literature Review}

Miller (1977) indicates that although the tax rate in 1950 is quintupled compared with 1920, the leverage of nonfinancial companies maintains almost in the same level in the United States [1]. Companies are not taking advantage of the tax benefit and following a low leverage policy, which is not consistent with the trade-off theory. For a period, it hasn't call for much attention from the scholars. In 2000, Graham found that according to the modern capital structure theory, the company value increase at least $15 \%$ with an optimal debt by the function of interest and tax yield through estimating the marginal tax rate sequence. Nevertheless, a number of large-scale profitable firms with better liquidity adopt a conservative debt policy to keep a low anticipation of the financial distress cost, though their optimal debt is far more than zero [2]. The "low leverage puzzle" commonly exists among these companies.

In recent years, a number of papers have investigated this phenomenon and scholars have analyzed the characteristics of the low leverage companies from different perspectives to search for the motives leading to the low leverage. Marchica and Mura (2010) found that if a company sustains a low leverage in the long term, it issues bonds to raise capital when there is a high capital expenditure or unconventional investment. The low leverage policy has a connection with the choice of the spread capital structure [3]. De Angelo et al. (2011) argue firms often take advantage of temporary debt to raise fund although there is a target capital structure. To reserve the capacity of debt financing for the desired projects in the future, they deliberately deviate from the long-term target leverage [4]. Morellec (2004) theoretically and empirically proves that, the low leverage phenomenon and the fact high growing firms using less debt, can be generated from the model of management-stockholders conflict [5]. Morellec's (2012) model can explain the mystery of low leverage of firms when the agency costs of manager equal to $1.5 \%$ of the equity value, which means the level of agency costs has an impact on the leverage option [6].

Booth et al. (2001) point out that the profitable companies have both much less demand for the external capital and lower liability ratio [7]. Milton and Wruck (2001) analyzed the characteristics of the low leverage companies by the sample of US companies from 1974 to 1998 and found that the low leverage companies keep high growth. The companies follow the pecking order theory and reserve their financing capability, in order to cope with the future expense and financial acquisition. Therefore, it is a temporary conservatism behavior which is not relative to the industry circumstance [8]. Dang (2013) analyzed the characteristics of UK debt-free firms from 1980 to 2007 and it shows, in comparison, firms that employ conservative debt policy are smaller, younger and more profitable. Furthermore, they hold large amount of cash, pay higher dividends and companies inclined to rely on equity financing. Zero leverage companies try to release the problem of lacking investment by financial conservatism. It is found that the more the companies deviated from the target leverage, the easier they would give up the zero leverage tactics. The extreme liability conservatism that employed by the companies is consistent with the dynamic trade-off theory [9].

Devos et al. (2012) attempt to inspect the influence of managerial entrenchment on the debt conservatism phenomenon by the sample of all the non-financial and non-public utility firms from 1990 to 2008. It proves that the internal and external governance mechanisms of debt-conservative companies are not weaker than others. Managerial entrenchment is not the explanation of the debt-free puzzle. On the other hand, funding constraints is the leading reason of the financial conservatism [10]. Using the sample of US listed companies from 1971 to

${ }^{1}$ These data are calculated according to China Shanghai \& Shenzhen A-share board market listed companies from CASMAR over the period 1993-2011. 
2002, Byoun and Xu (2013) seek for the relationship between financial characteristics, capital market conditions and the corporate zero leverage. It is found that the effective stock market assessment and debt constraints are the reasons for the firms to employ extreme liability conservatism. Small zero leverage firms raise their market reputation up through dividend distribution. While larger ones manage to reduce the managerial agency cost because their considerable profitability provide a cash surplus, which enable them to cover the investment without debt [11]. By studying the sample of CRSP and COMOPUSTAT corporation database from 1962 to 2009, Strebulaev and Yang (2013) point out that there is a declining trend of the leverage of the US listed companies and the industry and scale cannot perfectly explain the zero leverage puzzle. Statistics shows the zero leverage companies have smaller scale, higher profitability, better cash balance and the dividend distribution rate in comparison with the reference companies. In the mean time, the zero leverage situations almost exist in the growth period in the life cycle and the dividend distribution is not relevant with the leverage evaluation. Nonetheless, it is contrary to Devos's (2012) study that they verify the management characteristics and the corporation governance are relative to the zero leverage tactics [12].

Bessler et al. (2013) collect the financial and market statistics of G7 listed companies from 1989 to 2010 and document that zero debt does not only exist in the US listed companies, but is also an international phenomenon with a rising tendency. Moreover, it is proved that country-specific variables such as the vicissitude of the economic cycles and the capital market, contribute to the zero-debt option in G7 sample. The distinctions of percentage of zero-debt companies across G7 countries could be explained by the country-specific systems and legal nature, like origin financial systems, the creditor protection and etc. [13].

There are limited studies about the low leverage phenomenon in China. Wu (2006) indicate the company scale and the high operating inputs are the major motivations of the low leverage effect among high-tech companies [14]. Zhang and Chen (2013) find that the zero leverage companies across the real estate industry, in contrast to other industries, have smaller scale, less tangible assets, higher growth and is more sensitive to the macroeconomic environment. Monetary capital, short-term borrowing and Commercial Credit Financing supply are the significant factors affect the zero leverage policy [15]. Zhang et al. (2012) manage to explain the low leverage puzzle from the corporation efficiency perspective by stating a negative correlated exponential relationship between the corporation efficiency and leverage, which indicate that the more efficient the company is, the lower leverage it employs [16].

In conclusion, the study on low leverage relevant behavior is in the ascendant, whereas most of the papers focus on the developed countries and the developing countries are much less concerned. Nevertheless, as the world economic structure varies, the economic situation of developing countries significantly affects the world economic recovery. The companies in China, as the emerging market, are gaining considerably more attention from the world. Based on the capital market features in China, Zhang et al. (2012) insist the corporation efficiency could partially explain the low leverage puzzle in China from the perspective of the relationship between the corporation efficiency and the capital structure. However, in the modern corporation operation, the management affects the investment and financing decisions as the decision makers of company operation. Based on Zhang et al. (2012)'s study, it will be discussed that whether the management natures could be considered as a reason of the low leverage in China [16].

\section{Theoretical Background and Hypotheses}

The separation of ownership and operation of companies makes the management the practical administrators of the companies and the different management natures have an influence on the corporation decision making.

\subsection{Risk Preference and the Low Leverage}

There are considerable differences of the attitude towards risks among individuals. The risk preference generated from the psychology of each individual affect their behavior respectively. Under the two-right-separating corporate governance framework, manager's behavior is supervised and restricted by the board of directors, the creditors and so on. The "CEO Effect" exists in the investment and financial decisions that the manager's attitude and risk preference influence the corporate leverage policy. Risk-preference managers are more inclined to take advantage of the tax effect of debt interest to conduct higher liability financing; while the risk-averse managers tend to hold more cash to avoid financial pressures of debt, the reputation damage of bankruptcy and value loss, therefore more internal capital is considered when there is financing demands. Intuitively, the low debt level 
seems avoiding the cash flow crisis and the bankruptcy possibility. Bertrand and Schoar (2003), Coles et al. (2006) suggest that if the increasing debt inevitably makes the managers considering a higher risk towards the corporate value, the more risk-aversion they are, the less possible they would use the debt financing. On the other hand, they issue shares instead [17] [18].

In the modern corporations, the manager's agency cost could be reduced in order to stimulate the manager to make effort and the salary is connected with the corporate performance. Cadenillas et al. (2004) argues that if more incentive compensations are involved in the managerial pay, the managers whose risk aversion is low tend to follow a high leverage, on the contrary, the managers with high-risk-averse is reluctant to tolerate the risk of debt and they are inclined to take a low leverage for a better payment under little liability [19]. Lewellen (2006), Chava and Purnanandam (2010) indicate that there is a mutual effect between the risk-averse managers and the corporate capital structure. The risk-averse managers whose wealth is non-decentralized select a conservative liability policy, namely, low leverage and high cash holdings [20] [21].

H1: Corporations with risk-averse managers give rise to a higher possibility of employing low leverages.

\subsection{Overconfidence and Low Leverage}

People with overconfidence and optimism usually overestimate their capabilities. They are more optimistic when judging things and they believe the accuracy of the decisions is above average. According to the study of Graham et al. (2012), compared with ordinary people, the managers have much more firm mind. They appear to be more optimistic and confident, and self-judgment is more relied when perceiving things. When there is an investment financing project, managers inevitably overstate the return of investment project rather than the bankruptcy costs. Over-confident managers generally stay a higher liability level in debt financing as they believe it can provide substantially more benefit for the stockholders [22]. However, Malmendier et al. (2011) document that the over-confident managers with experience of the economic recession between 1929 and 1933 in the US are in favor of conservative debt policy [23].

H2: Leverage decision making of over-confident managers is uncertain.

\subsection{Other Characteristics and Low Leverage}

The different age and gender of managers could lead to different psychological cognition, thus interfere their behavior pattern. According to Chinese famous thinker and educator Qichao Liang's words, "The elder often think about the past while the young think about the future. The former tend to be conservative due to the experience of the past, but the latter are inclined to be radical because of the expectation of future." As a result, compared with the young managers, the elder managers are apparently more conservative in terms of the investment and financing behavior. They are willing to use the low-risk approach such as internal capital or stock equity rather than debt financing. In the occasion of inevitable liability financing, they choose a rather lower debt level and more cash holding [17] [24].

H3: Corporations with managers in mature years give rise to a higher possibility of employing low leverages.

Males are relatively more aggressive and adventurous than females. A male CEO regards the control power of corporate more important. Furthermore, he would rather choose active and bold debt financing to satisfy the demand of investment opportunities as he is more willing to take the responsibility. Huang and Kisgen (2013) indicate that corporate with female managers are under less debt level [25].

H4: Corporations with male managers give rise to a less possibility of employing low leverages.

\section{Research Design and Method}

\subsection{Variable Definition and Calculation}

As known, corporate liabilities are comprised of non-debt liabilities and debt financing. Non-debt liabilities mainly come from the day-to-day settlement program or the law and regulations. Debt financing is an active choice based on the actual corporate capital demand. In this study, the active capital structure arrangement is concerned. The financing option, namely the debt due to the external financing, presses more attention. Referenced to the regulations of Chinese financial system and the corporate operation practice, the active financing is defined as the summation of the short term borrowing, long-term debt due within one year, long term borrowing and the bongs payable in the balance sheet. The low leverage is defined when the asset-liability ratio 
is below $5 \%$.

$\mathrm{LEV}=\frac{\text { (long term borrowing }+ \text { short term borrowing }+ \text { bonds payable }+ \text { long term debt due within one year })}{\text { book assets }}$

Barros and Silveira (2008), Malmendier et al. (2011) argue that the overconfident managers hold more equity [26] [23]. Berger et al. (1997) find the defensive managers gain more resources, higher fixed remuneration and more shareholdings [27]. Therefore, the CEO shareholding (EHOLD) and CEO compensation (COMP) are considered as the proxies of the managerial over confidence and the risk preference.

In order to control the effect the corporate governance imposed on the managerial decision making, the ratio of the first strong stockholder is taken as the proxy variable of the corporate governance. Corporate ownership concentration strengthens the supervisory incentive of the major shareholder, so they may be more concerned of the manager's operating decisions. As a result, the administrational discretion power would be considerably restrained. In practice, the first strong shareholder possesses the actual administration authority as the ratio exceeds 33\%, which could be the constraint of the leverage option of individual manager.

Furthermore, firm's factors affecting the corporate capital structure: the size (SIZE), the profitability (ROA), the tangible assets (TANGI) and the growth (Q) are used as corporate characteristic variables. Titman and Wessels (1988), Frank and Goyal (2009) and Gu et al. (2007) indicate that the size of corporation, the value of tangible assets, the growth potential and the profitability capacity have an influence on the choice of capital structure. Debt capital support is superior to the large-size companies with preferable lending conditions so the expectation leverage is higher. The bigger the tangible assets value is, the higher the credit rating could be. With a desirable rating the cost of debt could be low enough to attract the company to choose debt financing. In order to avoid the negative effect of inadequate investment, high growth companies take advantage of the equity financing to manage the growing scale and therefore realize a low leverage (Table 1). The sufficient internal capital of profitable companies enables them to weaken the dependence of external debt on the one hand, or seek for the tax benefit by raise liability on the other hand. Therefore the relationship between profitability capacity and corporate leverage is uncertain [28]-[30].

\subsection{Measure Model}

Logistic regression model is used to examine the CEO characteristics and the corporate low leverage propensity.

Table 1. Variable definition and calculation.

\begin{tabular}{|c|c|c|}
\hline Variable & Symbol & Definition and Calculation \\
\hline Leverage & LEV & $\begin{array}{c}\text { (long-term borrowing }+ \text { short-term borrowing }+ \text { bonds payable }+ \text { long-term debt due } \\
\text { within one year)/(total book assets) }\end{array}$ \\
\hline Low leverage & LOWD & equal to 1 if the leverage is equal or lower $5 \%$, otherwise is 0 \\
\hline Long debt ratio & LDEBT & (long-term borrowing + bonds payable)/(book assets) \\
\hline Firm age & FAGE & all the year numbers after the firm build \\
\hline CEO age & AGE & CEO age \\
\hline CEO compensation & COMP & Log(CEO cash remuneration) \\
\hline CEO equity & EHOLD & (the number of CEO equity)/(total firm equity number) \\
\hline First shareholder's equity & FHOLD & (equity number of the first shareholder)/(total firm equity number) \\
\hline Firm size & SIZE & Log(total book assets) \\
\hline Profitability & ROA & (earnings after depreciation, interest, and taxes)/(total book assets) \\
\hline Growth & Q & (total market assets)/(total book assets) \\
\hline Collateral & TANGI & (net of fixed asset and construction in process)/(total book assets) \\
\hline $\begin{array}{l}\text { Cash holding } \\
\text { capital expenditure }\end{array}$ & $\begin{array}{l}\text { CASH } \\
\text { INVEST }\end{array}$ & $\begin{array}{l}\text { (monetary capital)/(total book assets) } \\
\text { (the capital which buy the fixed assets)/(total book assets) }\end{array}$ \\
\hline
\end{tabular}


The specific estimated model takes the following form.

$$
\operatorname{Logit}(P)=\alpha+\beta_{i} X_{i}+\varepsilon_{i}
$$

$$
P(Y=1 / X=x)=\frac{e^{x^{\prime} \beta}}{1+e^{x^{\prime} \beta}}
$$

In Equation (1), $X$ represents a vector of manager and firm characteristics that determine the low-leverage, $\beta_{i}$ is the vector of the coefficients, and $\alpha$ is the constant term, $\varepsilon_{i}$ is the residual term.

\subsection{Sample and Data}

The sample firms are chosen from the Shanghai Stock Exchange traded companies in China from 2007 to 2012. Firms in the sample have to satisfy the following criteria: Firstly, according to the international research practice, firms in the finance and insurance industry have been delisted due to the particularity of capital structure in the industry. Secondly, firms that have been regarding as "special treated" (ST), or "particular treated" (PT) are excluded from the sample because of the financial statement fraud or poor performance. Thirdly, firms with extremely abnormal data or missing financial data are delisted.

The procedure of sample collection is as follows: Firstly, firms with leverage below $5 \%$ are screened from the total up-to-standard sample; Secondly, the non-low leverage firms will be matched in the equal amount from the same industry respectively and the matching firm is within $\pm 5 \%$ of the original firm size. There are significant distinctions in the size of the firms in manufacturing industry on account of the considerable firm amount on the list. Therefore, different with matching by the first industry number in other industries, the secondary industry code is taken in the manufacturing industrial matching to guarantee the comparability; Thirdly, according to the firm code after matching, information including the CEO gender, age, equity ratio, compensation and so on is manually collected from the sample. Firms with missing CEO data together with its matching firm will be delisted. The final sample consists of 274 firms, 137 each of the original and matching sample.

\section{Empirical Results and Discussions}

\subsection{Summary Analysis}

As shown in Table 2, the leverage of sample firms reaches a maximum of $69.6 \%$ and a minimum of 0 . The leverage average is $18.3 \%$, which is less than the mean $24.85 \%$ in US firms [31]. The long-term debt ratio average peaks at $46.4 \%$ and bottom at of 0 . The average ratio is only $4.6 \%$ dramatically lower than the mean of $27 \%$ in the developed countries and $22 \%$ in developing countries [32]. The phenomenon of generally lower leverage and

\begin{tabular}{cccccc} 
Table 2. Summary statistics. & & & \\
\hline Variable & Mean & Std.Dev & Min & Median & Max \\
\hline LDEBT & 0.046 & 0.09 & 0 & 0 & 0.464 \\
LEV & 0.183 & 0.185 & 0 & 0.069 & 0.696 \\
FAGE & 17.3 & 3.3 & 4 & 19 & 26 \\
AGE & 48 & 6.6 & 33 & 48 & 63 \\
COMP & 5.506 & 0.356 & 4.401 & 5.556 & 6.239 \\
EHOLD & 0.008 & 0.027 & 0 & 0 & 0.141 \\
FHOLD & 0.352 & 0.149 & 0.087 & 0.335 & 0.838 \\
SIZE & 9.388 & 0.409 & 7.848 & 9.378 & 10.937 \\
CASH & 0.198 & 0.122 & 0.008 & 0.167 & 0.611 \\
ROA & 0.058 & 0.08 & -0.293 & 0.044 & 0.889 \\
TANGI & 0.313 & 0.214 & 0.001 & 0.264 & 0.879 \\
Q & 1.746 & 1.158 & 0.498 & 1.371 & 11.458 \\
\hline
\end{tabular}


long-term debt ratio is consistent with Liu et al. (2004)'s study: The first financing choice of listed companies in China if equity financing, then debt financing, and the short-term debt is preferable compared with long-term debt. The capital market imperfection and regulation constraints make the listed companies scarce resources and most of the companies were excess financed. Companies obtain considerable capital through the capital market so that no other financing instruments are demanded for a long period. Besides, the underdeveloped bond market and the supervision of commercial banks increase the difficulties of gaining the debt financing, which lead to a lower debt [33].

Table 2 also indicates an average annual salary of 430 thousand RMB of the CEOs in China listed companies. CEO shareholding ratio is significantly low with an average of less than $1 \%$, which is less than the mean of American firms (3.725\%). This phenomenon mostly resulted from the history of Chinese economic regime. Chinese firms are all the state-owned companies before the reform of economic system. Corporate staffs own no shareholding and the earnings mainly come from the wages. In 1990, in order to accelerate the reform of stateowned enterprises and improve the efficiency, China rebuilt the capital market. A number of state-owned companies went public through reorganization and the manager competitive mechanism and incentive system have been gradually introduced so that managers could be encouraged by equity to some extent. Yet the state-owned nature endows the corporate manager the double identity of not only the entrepreneur but also the politician. The incomes are more reflected in cash and bonus rather than equity incentive.

The youngest and eldest CEOs are 33 and 63 years' old, and the age mean is 48. An elder age mean is indicated in the data of CEOs. Among the companies in china, especially those state-owned ones, there is a strict hierarchy culture and promotion system which makes it difficult for the younger people to get in charge in the early time. Manager promoted to a high office need to experience more inspection and stages.

The largest shareholder's proportion of equity is $35.2 \%$ in average, that the maximum is as high as $83.8 \%$. This suggests there is a significant ownership concentration in China listed firms. Meanwhile, the board of firm could be controlled by major shareholders and corporate decisions and the CEO behavior may be interfered to fulfill large shareholder's own benefits.

In addition, distinction in the corporate size is demonstrated in Table 2 that the largest firm value is up to 86.4 billion RMB while the smallest is 70 million RMB and the value average is 4.02 billion RMB. There is also a substantial distinction in the tangible assets with the highest tangible assets proportion of $87.9 \%$ and lowest $0.1 \%$ in these companies. The data declares that the listed firms in China widely spread over various industries. It covers the traditionally industrial companies with larger fixed assets, and high-tech companies which are highly knowledge based and independent on the missive fixed assets.

The average proportion of the market capitalization to the assets is 1.746 , with a median of 1.746 , and maximum of 11.458. It illustrates that the growth of listed companies is of great difference. In the mean time, table 2 states that high grow companies possess larger cash holding ratio than those of low growth (0.611 vs. 0.008). The higher profitability $(0.889$ vs. -0.293$)$ shows that the high growth companies are more profitable and larger amount of cash is hold to deal with the future capital demand such as investment and so on.

\subsection{Comparative Analysis}

As shown in Table 3, in comparison with matching sample, the low leverage firms have a smaller size. On the one hand, the mean of cash holding, profitability and growth performance of the low leverage sample are exceeding the matching sample. On the other hand, the investment, tangible and intangible assets are below the average level of matching sample. In reality, young and small firms without sufficient asset mortgage are reluctant to gain the external financing when there is capital demand. They are facing more limitations since they haven't built a favorable reputation and history in the capital market [34]. On the occasion that they are unable to get sufficient finance support through a reasonably low cost, a low leverage will be chosen. In addition, if the profitability provides a large amount of free cash flow in operation, the low leverage policy will be employed with the excess capital reserved [2] [35]. Meanwhile, sufficient cash could ensure the adequate debt capacity to deal with future capital outlay [36]. As for the causes, companies are reluctant to get bond financing due to the undeveloped corporate bond market and the bank debt financing support is rather difficult to obtain because of the bank supervision and strict censorship. Moreover, the strict refinancing system and regulations of the stock market bring about more obstacles for the corporate refunding. In this case, companies are only able to attempt internal capital when there are investment opportunities. High growth companies are willing to choose low leverage and high cash holding to avoid capital inadequateness. Therefore, low leverage companies manifest as 
small sized, young, highly profitable, high capital outlay, more cash flow and financing limited.

According to Table 3, there are remarkable distinctions between the low leverage companies and the matching sample in terms of the CEO compensation, CEO equity ratio and the first large stockholding. Means of these variables are considerably beyond the matching companies. Nevertheless, there is no substantial difference in the corporate years and CEO age.

Table 4 indicates that there is no significant distinction in the firm characteristics in terms of company size, cash holding, tangible assets and growth capability between two CEO gender corporate groups. However, corporate leverage has significant difference in the distinguished gender operated companies as the leverage of firm with male manager is larger than that firm's with female manager (19\% vs. 3.7\%). This suggests male CEOs have stronger adventurous spirit than female, which is similar with the other countries in the world. From it

Table 3. Comparison analysis of low leverage firms and matching firms.

\begin{tabular}{ccccc}
\hline Variable & Low Leverage Firms & Matching Firms & Difference of Mean & t Test \\
\hline LDEBT & 0.002 & 0.088 & -0.086 & $-9.032^{* * *}$ \\
LEV & 0.013 & 0.35 & -0.337 & $-36.310^{* * *}$ \\
FAGE & 17.37 & 17.25 & 0.11 & 0.286 \\
AGE & 48.16 & 47.81 & 0.35 & 0.435 \\
COMP & 5.543 & 5.47 & 0.073 & $1.702^{*}$ \\
EHOLD & 0.012 & 0.005 & 0.007 & $2.224^{* *}$ \\
FIHOLD & 0.38 & 0.324 & 0.056 & $3.169^{* * *}$ \\
SIZE & 9.291 & 9.483 & -0.191 & $-3.976^{* * *}$ \\
CASH & 0.25 & 0.146 & 0.104 & $7.728^{* * *}$ \\
ROA & 0.084 & 0.033 & 0.051 & $5.539^{* * *}$ \\
TANGI & 0.287 & 0.338 & -0.051 & $-1.986^{* *}$ \\
Q & 1.977 & 1.519 & 0.458 & $3.319^{* * *}$ \\
\hline
\end{tabular}

Note: ${ }^{* * *},{ }^{* *}$, and ${ }^{*}$ indicate statistical significance at the $1 \%, 5 \%$, and $10 \%$ levels, respectively.

Table 4. Distinctions analysis with different CEO gender.

\begin{tabular}{ccccc}
\hline Variable & Male & Female & Difference of Mean & t Test \\
\hline LDEBT & 0.048 & 0.003 & 0.045 & $7.116^{* * *}$ \\
LEV & 0.19 & 0.037 & 0.153 & $5.435^{* * *}$ \\
FAGE & 17.345 & 16.615 & 0.729 & 0.779 \\
AGE & 47.831 & 51.077 & -3.246 & $-1.724^{*}$ \\
COMP & 5.505 & 5.534 & -0.03 & -0.291 \\
EHOLD & 0.008 & 0.001 & 0.008 & $4.467^{* * *}$ \\
FIHOLD & 0.349 & 0.396 & -0.046 & -1.097 \\
SIZE & 9.389 & 9.366 & 0.023 & 0.194 \\
CASH & 0.196 & 0.233 & -0.037 & -1.054 \\
ROA & 0.057 & 0.074 & -0.017 & -0.742 \\
TANGI & 0.316 & 0.249 & -0.019 & -0.235 \\
\hline
\end{tabular}

Note: ${ }^{* * *},{ }^{* *}$, and ${ }^{*}$ indicate statistical significance at the $1 \%, 5 \%$, and $10 \%$ levels, respectively. 
came into the male dominated society, males began to bear more social and family responsibilities. It makes males more confident and sometimes they are even likely to be over confident. As a result, males are willing to undertake more debt in the same operation conditions. Their confidence in their management ability makes them believe that more debt would bring higher return, though it is not always the case.

It is known from Table 4 that CEO with two genders are holding different amount of equity shareholding. Male CEO has more equity shareholding of their managerial company than that of female CEO in average. The difference is signally at the $1 \%$ level that shareholding for men average is $0.8 \%$ and only $0.1 \%$ for women.

In Table 4, the age between male CEO and female CEO also has differences at a level that women CEO are older than men on the average. It spends more time for women to get the promotion in their career than men. In the patriarchal society, women have been given the role of mothers and homemakers etc, so they have to make greater effort and spend more time to prove themselves if they want to get approved and win the success.

\subsection{Regression Results}

Table 5 shows the logistic regression result. The dependent variable is a dummy variable that takes the value "1" for firms with debt less than or equal to $5 \%$, otherwise 0 . In all regressions, the corporate size, profitability capacity, tangible assets and growth capacity are controlled.

Table 5 indicates that the debt conservatism and low leverage is inclined to be employed when there is a higher CEO equity shareholding, more compensation and elder age. Characteristics of CEOs could affect the corporate capital structure decisions. In China, due to the influence of Confucian culture, the CEOs appear to be more cautious and modest than those in western countries. Managers prefer to follow low leverage policy under the similar conditions so that the bankruptcy risk could be avoided and financial loss by excess interest could be reduced. Hence, relationship between CEO shareholding, compensation and the corporate leverage option greatly more reflects the CEO risk preferences. In addition, as the CEOs get elder and their career life shortens, it is a descending trend of their willingness and capability to undertake risk. Their behavior and decision tend to be conservative, therefore they are inclined to reduce the debt financing and follow the low leverage policy.

The regression results suggest the CEO gender is associated with the debt application. It offers support to the manager preference hypothesis that companies with male CEOs are using higher leverage. Compared with female CEOs, the male ones are much more confident and less risk averse. Meanwhile they are willing to increase the corporate and personal earnings through the utility of leverage.

Table 5. The results of logistic regression.

\begin{tabular}{|c|c|c|c|c|c|c|c|c|}
\hline & (1) & (2) & (3) & (4) & (5) & (6) & (7) & (8) \\
\hline GENDER & & & & & $-2.388^{* *}$ & & & $-2.011^{*}$ \\
\hline CONCUR & & & & & & & 0.24 & 0.185 \\
\hline AGE & & & & $0.041^{*}$ & & & & $0.041^{*}$ \\
\hline COMP & & & 0.169 & & & & & 0.346 \\
\hline EHOLD & & 2.621 & & & & & & $10.738^{*}$ \\
\hline FHOLD & & & & & & $3.311^{* * *}$ & & $3.797^{* * *}$ \\
\hline SIZE & $-1.739^{* * *}$ & $-1.702^{* * *}$ & $-1.784^{* * *}$ & $-1.909^{* * *}$ & $-1.781^{* * *}$ & $-1.823^{* * *}$ & $-1.839^{* * *}$ & $-2.013^{* * *}$ \\
\hline ROA & $19.949^{* * *}$ & $19.709^{* * *}$ & $19.567^{* * *}$ & $20.494^{* * * *}$ & $19.471^{* * *}$ & $18.677^{* * *}$ & $20.249^{* * *}$ & $16.846^{* * *}$ \\
\hline TANGI & -0.941 & -0.855 & -0.886 & $-1.287^{*}$ & -0.868 & -1.129 & -0.931 & -0.926 \\
\hline $\mathrm{Q}$ & 0.037 & 0.041 & 0.028 & 0.018 & 0.015 & 0.139 & 0.037 & 0.106 \\
\hline INTERCEPT & $15.497^{* * *}$ & $15.103^{* * *}$ & $15.012^{* * *}$ & $15.233^{* * *}$ & $18.233^{* * *}$ & $15.099^{* * *}$ & $16.315^{* * *}$ & $14.686^{* * *}$ \\
\hline Pre Pro & $73.70 \%$ & $73.40 \%$ & $73.40 \%$ & $75.90 \%$ & $75.90 \%$ & $77.40 \%$ & $74.10 \%$ & $78.10 \%$ \\
\hline Pseudo-R ${ }^{2}$ & 0.315 & 0.316 & 0.316 & 0.327 & 0.345 & 0.35 & 0.317 & 0.395 \\
\hline Observations & 274 & 274 & 274 & 274 & 274 & 274 & 274 & 274 \\
\hline
\end{tabular}

Note: ${ }^{* * *},{ }^{* *}$, and ${ }^{*}$ indicate statistical significance at the $1 \%, 5 \%$, and $10 \%$ levels, respectively. 
It makes little difference of the corporate capital structure that whether the CEO has another position at the same time. As a matter of fact, CEO concurrent position has its own characteristics in Chinese firms. Normally, a number of them hold both posts of CEO and chairman of the board, or stay in a superior position in the group company. In the case, there is no conflict of interest between the CEO concurrence and their own work so that the corporate decisions are not interfered.

Table 5 also indicates that, the larger the first large shareholding is, the higher the possibility of taking low leverage is. The corporate governance is associated with the capital structure option. The corporate size is negative correlated with the possibility of low leverage. It coincides with the traditional study conclusion that the size is positively correlated with the leverage. The considerable corporate scale delivers positive information to the market. The leverage tends to be high because it is easier for the companies to obtain capital from the market. The profitability is negative correlated with the low leverage that the more profitable the company is, the lower the leverage would be. It demonstrates that the sufficient internal capital resulting from the profitability make the managers and shareholders to have less borrowing to avoid the interest loss of debt rent. Moreover, the corporate leverage goes negatively with the value of tangible assets. Considerable amount of tangible and collateralizable assets make it easy to debt more so that the companies could enjoy the tax benefit from paying the debt interest. The growth pace is positively correlated with the low leverage, yet the influence is non-significant.

\section{Conclusions}

Taking the listed companies in China as the object sample, this paper makes use of Independent sample mean inspection and the logistic regression model to empirically analyze the inducements of the low leverage policy from the perspective of the characteristics of management. Study result indicates that, in China: the CEO risk preference affect the leverage decision that risk-averse CEO choose the low leverage; CEO age is positive correlated with the low level option that elder CEOs prefer a more conservative capital structure; Firms with female CEOs are inclined to adopt low leverage in comparison with male.

This study is a supplement to the evidences of low leverage option in the emerging market. It not only strengthens the research conclusions of current corporate "low leverage puzzle", but also provides the relevant suggestion and reference in terms of the corporate design of managerial compensation system and selection and appointment of the manager.

\section{Acknowledgements}

We are grateful to two anonymous reviewers for their helpful comments and suggestions. We would also like to thank the support from the fund of national natural science of China (71371113); the fund of humanities and social science for youth researcher of ministry of education (12 yjc790251); the base project of college humanities and social science of Shanxi Province (2013303).

\section{References}

[1] Miller, M.H. (1977) Debt and Taxes. The Journal of Finance, 32, 261-275.

[2] Graham, J.R. (2000) How Big Are the Tax Benefits of Debt. The Journal of Finance, 55, 1901-1941. http://dx.doi.org/10.1111/0022-1082.00277

[3] Marchica, M. and Mura, R. (2010) Financial Flexibility, Investment Ability and Firm Value: Evidence from Firms with Spare Debt Capacity. Journal of Financial Management, 39, 1339-1365. http://dx.doi.org/10.1111/j.1755-053X.2010.01115.x

[4] DeAngelo, H., DeAngelo, L. and Whited, T. (2011) Capital Structure Dynamics and Transitory Debt. Journal of Financial Economics, 99, 235-261. http://dx.doi.org/10.1016/j.jfineco.2010.09.005

[5] Morellec, E. (2004) Can Managerial Discretion Explain Observed Leverage Ratios? Review of Financial Studies, 17, 257-294. http://dx.doi.org/10.1093/rfs/hhg036

[6] Morellec, E., Nikolov, B. and Schurhoff, N. (2012) Corporate Governance and Capital Structure Dynamics. The Journal of Finance, 3, 803-847. http://dx.doi.org/10.1111/j.1540-6261.2012.01735.x

[7] Booth, L., Aivazian, V., Demirguc-Kunt, A. and Maksimovic, V. (2001) Capital Structures in Developing Countries. Journal of Finance, 56, 87-130. http://dx.doi.org/10.1111/0022-1082.00320

[8] Minton, B.A. and Wruck, K.H. (2001) Financial Conservatism: Evidence on Capital Structure from Low Leverage Firms. Working Paper, Unpublished. 
[9] Dang, V.A. (2013) An Empirical Analysis of Zero-Leverage Firms: Evidence from UK. International Review of Financial Analysis, 30, 189-202. http://dx.doi.org/10.1016/j.irfa.2013.08.007

[10] Devos, E., Dhillon, U., Jagannathan, M. and Krishnamurthy, S. (2012) Why Are Firms Unlevered? Journal of Corporate Finance, 18, 664-682. http://dx.doi.org/10.1016/j.jcorpfin.2012.03.003

[11] Byoun, S. and Xu, Z. (2013) Why Do Some Firms Go Debt Free? Asia-Pacific Journal of Financial Studies, 42, 1-38. http://dx.doi.org/10.1111/ajfs.12009

[12] Strebulaev, I.A. and Yang, B. (2013) The Mystery of Zero-Leverage Firms. Journal of Financial Economics, $109,1-23$. http://dx.doi.org/10.1016/j.jfineco.2013.02.001

[13] Bessler, W., Drobetz, W., Haller, R. and Meier, I. (2013) The International Zero-Leverage Phenomenon. Journal of Corporate Finance, 23, 196-221. http://dx.doi.org/10.1016/j.jcorpfin.2013.08.004

[14] Wu, B. (2006) A Study of Influence Factors on Low Leverage of China’s High-Tech Firms. Statistics and Decisions, 9, 126-127.

[15] Zhang, X. and Chen, X. (2013) The Determinants of the Phenomenon of Zero-Leverage Firms in the Listed Real Estate Industry. The Theory and Practice of Finance and Economics, 3, 78-81.

[16] Zhang, X.D., Ni, L. and Chen, Y.P. (2012) “Lower Leverage Puzzle” in China’s Listed Firms: An Empirical Study Based on Firm Efficiency. International Journal of Management and Enterprise Development, 12, 54-72. http://dx.doi.org/10.1504/IJMED.2012.046793

[17] Bertrand, M. and Schoar, A. (2003) Managing with Style: The Effect of Managers on Firm Policies. Quarterly Journal of Economics, 118, 1169-1208. http://dx.doi.org/10.1162/003355303322552775

[18] Cole, J.L., Naveen, D.D. and Naveen, L. (2006) Managerial Incentives and Risk-Taking. Journal of Finance Economics, 79, 431-468. http://dx.doi.org/10.1016/j.jfineco.2004.09.004

[19] Cadenillas, A., Cvitanić, J. and Zapatero, F. (2004) Leverage Decision and Manager Compensation with Choice of Effort and Volatility. Journal of Financial Economics, 73, 71-92. http://dx.doi.org/10.1016/j.jfineco.2003.06.003

[20] Lewellen, K. (2006) Financing Decisions When Managers Are Risk Adverse. Journal of Financial Economics, 82, 551-590. http://dx.doi.org/10.1016/j.jfineco.2005.06.009

[21] Chava, S. and Purnanandam, A. (2010) CEOs versus CFOs: Incentive and Corporate Policies. Journal of Financial Economics, 97, 263-278. http://dx.doi.org/10.1016/j.jfineco.2010.03.018

[22] Graham, J.R., Harvey, C. and Puri, M. (2013) Managerial Attitudes and Corporate Action. Journal of Financial Economics, 109, 103-121. http://dx.doi.org/10.1016/j.jfineco.2013.01.010

[23] Malmendier, U., Tate, G. and Yan, J. (2011) Overconfidence and Early-Life Experiences: The Effect of Managerial Traits on Corporate Financial Policies. The Journal of Finance, 66, 1687-1733. http://dx.doi.org/10.1111/j.1540-6261.2011.01685.x

[24] Graham, J.R. and Harvey, C.R. (2001) The Theory and Practice of Corporate Finance: Evidence from the Field. Journal of Financial Economics, 60, 187-243. http://dx.doi.org/10.1016/S0304-405X(01)00044-7

[25] Huang, J. and Kisgen, D.J. (2013) Gender and Corporate Finance: Are Male Executives Overconfident Relative to Female Executives? Journal of Financial Economics, 108, 822-839. http://dx.doi.org/10.1016/j.jfineco.2012.12.005

[26] Barros, L. and Silveira, A. (2008) Overconfidence, Managerial Optimism, and the Determinants of Capital Structure. Brazilian Review of Finance, 69, 293-335.

[27] Berger, P., Ofek, E. and Yermack, D. (1997) Managerial Entrenchment and Capital Structure Decisions. The Journal of Finance, 52, 1411-1438. http://dx.doi.org/10.1111/j.1540-6261.1997.tb01115.x

[28] Titman, S. and Wessels, R. (1988) The Determinants of Capital Structure Choice. The Journal of Finance, 43, 1-19. http://dx.doi.org/10.1111/j.1540-6261.1988.tb02585.x

[29] Frank, M. and Goyal, V. (2009) Capital Structure Decisions: Which Factors Are Reliably Important? Finance Management, 38, 1-37. http://dx.doi.org/10.1111/j.1755-053X.2009.01026.x

[30] Gu, E., Zhang, C. and Sun, J. (2007) A Discriminating Research of the Core Influence Variables of Capital Structure. Contemporary Finance \& Economics, 1, 41-48.

[31] Flannery, M. and Rangan, K. (2006) Partial Adjustment toward Target Capital Structures. Journal of Financial Economic, 79, 469-506. http://dx.doi.org/10.1016/j.jfineco.2005.03.004

[32] Molina, C.A. (2005) Are Firms Underleveraged? An Examination of the Effect of Leverage on Default Probabilities. The Journal of Finance, 60, 1427-1459. http://dx.doi.org/10.1111/j.1540-6261.2005.00766.x

[33] Liu, X., Wei, F., Zhan, Y. and Tai, B.Y. (2004) An Empirical Analysis of China Listed Firms Financing Order. Accounting Research, 6, 66-72.

[34] Benmelech, E. and Bergman, N. (2009) Collateral Pricing. Journal of Financial Economics, 91, 339-360. 
http://dx.doi.org/10.1016/j.jfineco.2008.03.003

[35] Almeida, H., Campello, M. and Weisbach, M.S. (2004) The Cash Flow Sensitivity of Cash. Journal of Finance, 59, 1777-1804. http://dx.doi.org/10.1111/j.1540-6261.2004.00679.x

[36] DeAngelo, H. and DeAngelo, L. (2007) Capital Structure, Payout Policy, and Financial Flexibility. Working Paper, Unpublished. 
Scientific Research Publishing (SCIRP) is one of the largest Open Access journal publishers. It is currently publishing more than 200 open access, online, peer-reviewed journals covering a wide range of academic disciplines. SCIRP serves the worldwide academic communities and contributes to the progress and application of science with its publication.

Other selected journals from SCIRP are listed as below. Submit your manuscript to us via either submit@scirp.org or Online Submission Portal.
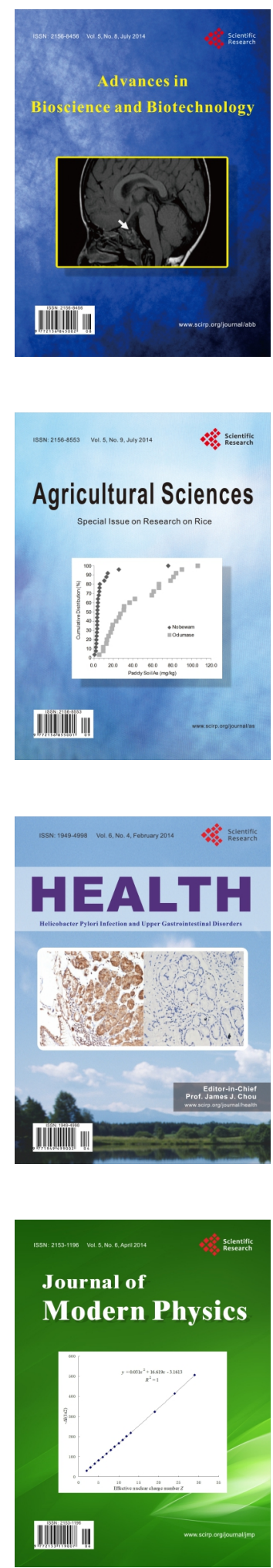
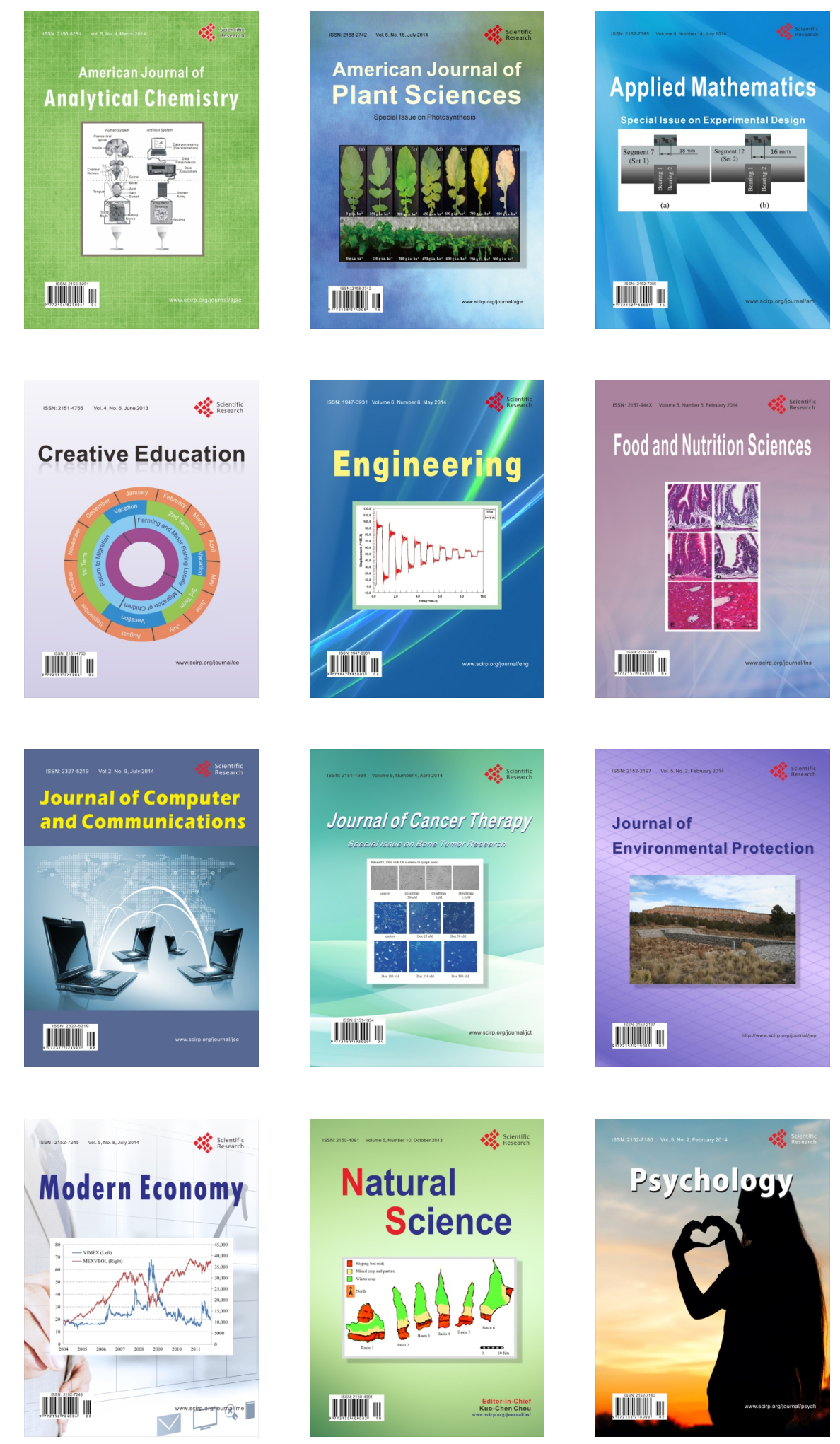